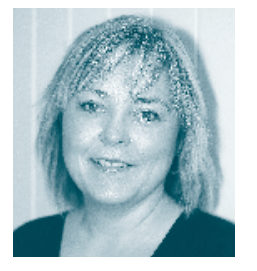

Elin Ose Velle, Volda Sjukehus, Helse Sunnmøre.

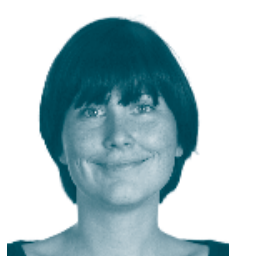

Ragnhild Øye Bjarkøy, Sente for kunnskapsbasert praksis, Høgskolen i Bergen.

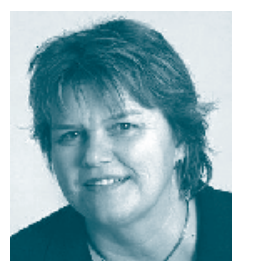

Marit Graue, Institutt for sykepleie, Høgskolen i Bergen.

$\AA$ meistre diabetes kan lærast

\author{
Pasientar med nyoppdaga diabetes type 1 treng støtte og vegleiing \\ frå sjukepleiar ved debut av sjukdommen.
}

D iabetes er ein utbredt sjukdom og stadig fleire får diagnosen. Sjukepleiarar møter ofte denne pasientgruppa i debutfasa, ei fase der den som har fått diabetes opplever nye og uventa krav som vil påverke dagleglivet. Å forstå korleis den enkelte pasient taklar å ha fått diabetes, og å hjelpe han eller ho til å meistre og leve med diagnosen, er ei utfordring, men ei svært viktig oppgåve for sjukepleiarar. Helsepersonell må forsøke å redusere det kjenslemessige presset for den som har blitt sjuk, slik at han kan ta i bruk positive meistringsstrategiar. Pasientane må lære tekniske ting som å sette insulin og måle blodsukker, men sjukepleiarar må være bevisst på korleis den enkelte taklar det å ha fătt ein kronisk sjukdom og hjelpe han eller henne til eit godt grunnlag for å leve med diabetes.

\section{Lovpålagt opplæring}

Å leve med kronisk sjukdom kan være ei stor påkjenning og kjelde til bekymring, og personar med slike sjukdommar har auka risiko for å utvikle psykiske helseplager. Dei som ikkje kjem i mål med behandlinga si slit ofte med depresjon, angst og motløyse (3). I samsvar med lova om spesialisthelseteneste er opplæring av pasientar og pårørande ei lovpålagt oppgåve for sjukehusa. Det leggjast vekt på at: «Like viktig som god medisinsk behandling er derfor god opplæring og meistring av sjukdomen. Mangel på opplæring er like alvorlig som mangel på medisinar og gode behandlingsformer. Opplæring er ein føresetnad for meistring av livet som kronisk sjuk, og for å forhindre forverring av sjukdommen og utvikling av alvorlige komplikasjonar.»(4).

Opplæring i å meistre stress, skade og sjukdom er ein av hovudstrategiane for å betre helsa til befolkninga generelt, både nasjonalt og internasjonalt. Nyoppdaga diabetes stiller store krav til den som har fått sjukdomen, og det meste av det som skjer i kvardagen får på ein eller annan måte tyding for behandlingsvurderingar og behandlingsresultat (5). Eigenkontroll er viktig i kvardagen for menneske med diabetes (6). Sjukepleiarar møter desse pasientane ved diagnosetidspunktet. God behandling og tilrettelegging er viktig i dette tidsrommet for at pasientane skal ha føresetnad om å møte desse krava og klare å handtere behandlinga i framtida (7). Det er difor interessant å sjå nærare på korleis sjukepleiarar kan møte desse pasientane på best mogleg måte, i det ofte korte tidsrommet dei er innlagde på sjukehus for utredning av sjukdommen og opplæring, til å meistre å leve livet med diabetes.

\section{Meistringsomgrepet}

Lazarus \& Folkman sin prosessmodell har vore under utvikling sidan 1960-talet. Teorien legg vekt på at menneske bruker ulike tilnærmingar for å meistre endringar avhengig av erfaring, samt grad og type stress. Meistring er knytt til oppleving av kontroll (8). Lazarus (9) skil mellom emosjonelt fokuserte meistringsstrategiar, der ein forsøker å påverke si eiga oppfatning av situasjonen, og problemfokuserte meistringsstrategiar, der ein prøver å påverke omgjevnaden.

Korleis vi handlar og kva meistringsstrategiar vi vel seier noko om personlegdomen vår. Alle menneske har sin eigen måte å meistre ting på, avhengig av eigne ressursar og erfaringar ein har gjort seg gjennom livet, samt sosial støtte og samanheng. Dette betyr at hendingar og situasjonar ikkje per definisjon er stressande, men det er den enkelte sine personlege opplevingar av stress som er gyldige. I kva grad personen har tiltru til eiga meistringsevne er ein annan psykologisk ressurs Lazarus \& Folkman beskriv. Lazarus framstiller sin modell for meistring som ein dynamisk prosess. Bevisst eller ubevisst vurderer vi alle om ein situasjon er farlig eller utfordrande for oss. Vi tek med i vurderinga korleis situasjonen vil påverke vårt velvære og kva ressursar som er tilgjengelige for å meistre utfordringane.

\section{Støtte og vegleiing}

Å leve med diabetes betyr å gjøre behandlingsvurderingar døgnet rundt. Det er vist at berre 20 prosent med type 1 diabetes klarer å oppnå behandlingsmål for HbA1c (10). Forsking har og vist at dei psykologiske forholda som ein skal meistre kan opplevast og handsamast ulikt frå person til person og at opplevingane 


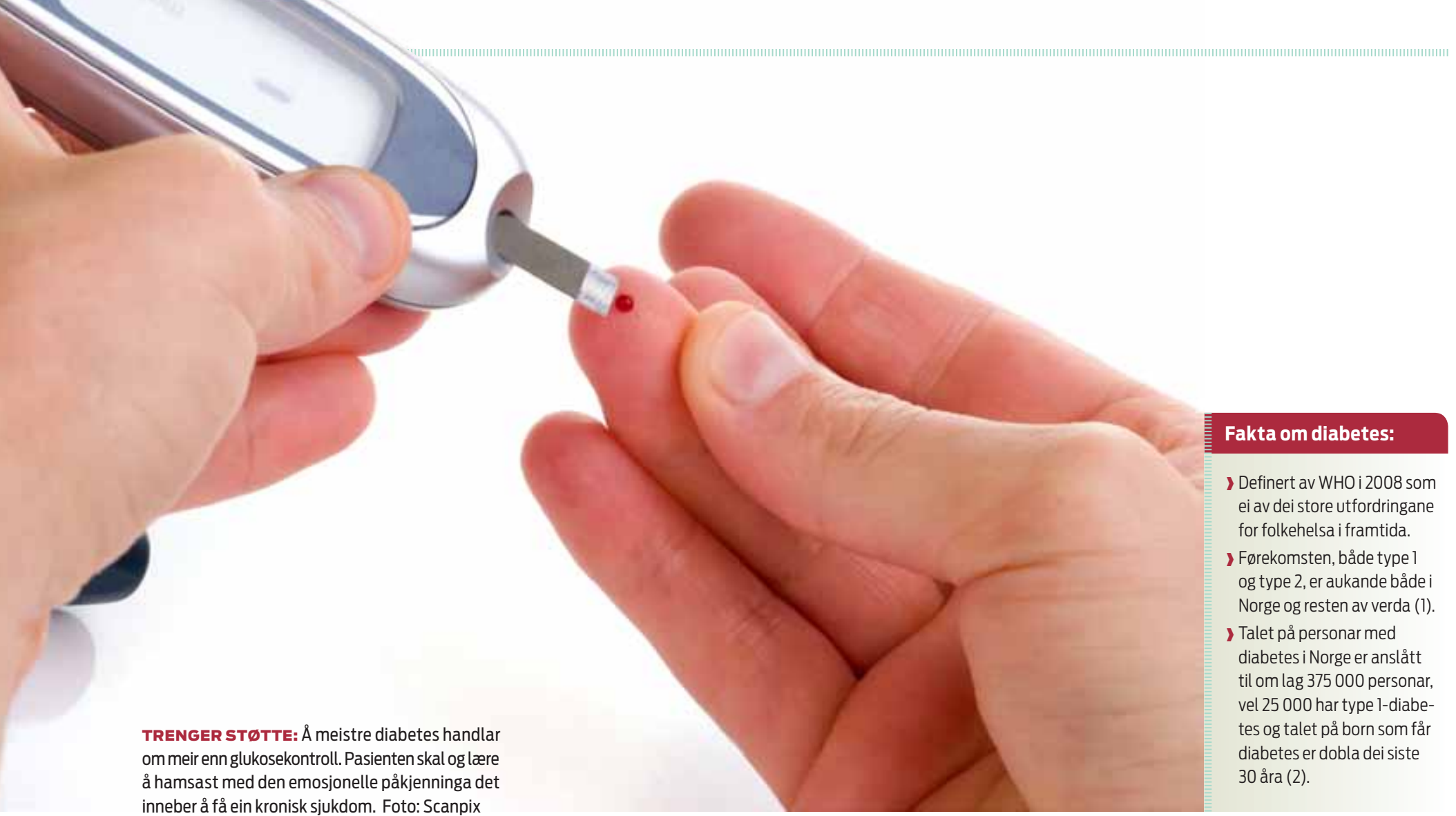

personar har ved diabetesdebut kan påverke resten av livet (7). Dette skapar store utfordringar for helsepersonell som møter pasientar med nyoppdaga diabetes. Det er difor viktig å reflektere over korleis helsepersonell generelt og sjukepleiarar spesielt kan støtte og vegleie pasientane til god oppfølging av denne livsvarige sjukdommen. Ifølge Peyrot og Rubin (11) er hovudoppgåva til helsepersonell som arbeider med menneske med diabetes å støtte dei og undervise i å utføre nødvendig eigenomsorg. Karlsen \& Bru (12) hevdar at personar som klarer å planlegge, søke informasjon og støtte, lære eigenkontroll og fylgje behandlingsregime har betre glukosekontroll og erfarer lågare nivå av depresjon og angst. Det ser ut til å være stor semje om at helsepersonell må sjå på pasientane si psykiske helse i større grad, men at behandlarane ofte manglar ressursar for å gjere dette; særleg kunnskap, evner, tid og adekvate tilvisningsressursar (13).

\section{Kompleks situasjon}

Pasienten kan føle det er overveldande å ha fått ein kronisk sjukdom, og nokre slit med skuldkjensle og skam. Som sjukepleiar er det viktig at ein oppdagar korleis situasjonen opplevast for den enkelte pasient, slik at ein kan støtte og rettleie pasienten ut i frå hans eller hennar situasjon. Helsepersonell må gje informasjon om sjukdomen, om bakgrunn for sjukdommen, om behandling og stimulere til eigenkontroll. Men fordi situasjonen er kompleks er det viktig at sjukepleiar ikkje berre informerer, men også ser til at pasienten tilegnar seg kunnskapen.

Ved debut av diabetes type 1 er det vanleg med fysisk ubehag med stort vekttap, ekstrem tørste, polyuri, slappheit og synsforstyrringar. Ser ein dette i lys av Lazarus sin meistringsteori, gjer pasienten ein primærvurdering der han vurderer om dette opplevast som farleg eller utfordrande. Opplevinga ved sjukdomsdebut er avhengig av personen si subjektive vurdering av det som skjer. Kanskje fornektar ein både fakta og implikasjonar for å avslå vissheita om det verste, slik at ein kan handle som om det ikkje gjorde noko. For dei som i denne perioden nyttar emosjonsbaserte strategiar - med ein heller destruktiv tankegang - er det viktig å forklare at det er normalt å kjenne det slik, men at kjenslene må bearbeidast for å kome vidare i meistringsprosessen.

Både problem- og emosjonsbaserte meistringsstrategiar kan være nyttige og utfylle kvarandre i meistringsprosessen, og kanskje kan sjukepleiarar med hell hjelpe pasienten til å meistre denne perioden ved å rette fokus mot meir problemfokuserte strategiar. Til dømes kan ein gå inn for å lære mest mogleg om praktiske ting som følgjer med sjukdommen. Å forstå korleis blodsukkeret svingar, å lære seg å måle blodsukker og å sette insulin kan gjere at ein kjenner seg fysisk friskare, og dét skaper tryggleik. Dette er aspekt som kan føre til oppleving av kontroll og dermed gi pasienten positive opplevingar av meistring.

\section{Meistringsressursar}

Mellom primærvurdering og meistring meiner Lazarus og Folkman at personen føretek ei ny vurdering, sekundærvurderinga (8). I denne fasa vurderar personen kva mogligheiter han har for å takle stresset eller ubehaget. Personen sine meistringsressursar er dei ressursar eller mangel på ressursar som er avgjerande for korleis han taklar påkjenninga. Korleis vert livet mitt no som

\section{Å leve med diabetes betyr å gjøre behandlingsvurderingar døgnet rundt.}

kronisk sjuk? Korleis kjem dette til å gå? Kan eg leve eit normalt liv? Her må sjukepleiar observere personen og samtale med han om korleis han opplever dette.

Karlsen et al. (14) har sett på om gruppebasert vegleiing medfører reduksjon i diabetesrelatert stress, auka grad av meistring, psykologisk velvære og glykemisk kontroll nærare eit akseptabelt nivå. Pasientgruppa er vaksne pasientar med type 1 og type 2 diabetes. Resultata viste at gruppebasert vegleiing kan ha potensiale. I Karlsen et al. (15) sin studie om gruppebasert rådgivingsprogram i diabetesrelatert stress såg ein signifikante forskjellar i problemfokusert og emosjonsfokusert meistring. 
Deltakarane i intervensjonsgruppa som deltok på desse kursa rapporterte meir optimisme og tru på eiga evne til å meistre livet med diabetes. Deltakarane vart meir motiverte og aktive i å ta del i å regulere sin diabetes og dei hadde mindre skuldkjensle. Som eit tillegg til støtte og vegleiing av kvar enkelt pasient, kan det difor vere hensiktsmessig med grupperettleiing. Kanskje kan pasientane også ha nytte av å oppleve at det er andre som har liknande utfordringar som dei sjølv.

\section{For stort medisinsk fokus?}

Når ein person vert innlagt i sjukehus med nyoppdaga diabetes er helsepersonell opptekne av metabolsk kontroll, og hovudfokus i opplæring er gjerne på tekniske ting som blodsukkermåling, injeksjonsteknikk og korleis blodsukker svingar i høve til kost, insulin og aktivitet. Frå helsepersonell si side er meistring i denne fasen sett på som at personen klarer å sette insulin og måle blodsukker. Dette er rett nok viktig for at pasienten skal klare dette sjølv i etterkant av sjukehusopphaldet, men er det tilstrekkelege mål i behandling før utskriving?

Mange har det vanskelig etter utskriving frå sjukehus. Fleire studium viser at personar med diabetes, både vaksne og ungdommar, kan tene betydelig på å lære meistringsstrategiar som dei kan nytte ved å handtere sin diabetes (16). Sjukepleiarar kan motivere personar med diabetes til meistring på fleire måtar. Å bli innlagt på sjukehus kan vere stressande. Innlagde pasientar

\section{Diabetes doblar risikoen for å utvikle ein følgjetilstand med depresjon.}

med nyoppdaga diabetes får mykje informasjon på kort tid og skal samstundes halde seg til at han har blitt kronisk sjuk. Det kan vere vanskeleg å tilegne seg den kunnskapen som kvardagen med diabetes krev. Det er helsepersonellet sitt ansvar å legge til rette for at den enkelte person skal inneha tilstrekkeleg kunnskap etter opphaldet på avdelinga. Korleis helsepersonell møter den enkelte pasient er difor viktig for å gje tilpassa informasjon. Det overordna målet for innlegginga er metabolsk stabilisering og kontroll. I løpet av den korte perioden pasienten er innlagt, får kanskje ikkje helsepersonell tid til å verte tilstrekkeleg kjende med personen.

\section{Pårørande bør inkluderast}

Ein meistringsmodell som omfattar det akutte kan vere viktig for å oppdage korleis pasienten opplever debut av sjukdommen og hjelpe pasienten til eit godt grunnlag vidare. Karlsen et al. (15), såg på samenhangar mellom støtte frå helsepersonell og familie, diabetesrelatert meistring og psykologisk velvære blant vaksne med type 1 og type 2 diabetes. Funna frå denne studien indikerar at støtte frå familien er nærare knytt til diabetesrelatert meistring enn støtte frå helsepersonell. Dette antyder at sjukepleiarar bør inkludere personens pårørande i perioden pasienten er innlagd, dersom dette er eit ønske frå pasienten.

Pouwer et al. (17) såg i sin studie på kor ofte diabetessjukepleiarar registrerte emosjonelle problem hos personar med diabetes og fann at frekvensen av slike registreringar var lav. Det er eit tankekors når ein kjenner omfanget av slike vanskar. Diabetesrelaterte emosjonelle vanskar slik som frykt for hypoglycemi, bekymringar for komplikasjonar eller å ikkje akseptere at ein har fătt diabetes kan gjere handteringa av sjukdomen vanskelig (11). Utfordringa i det daglige livet er å søke balanse mellom krava som vert stilte til god regulering og livskvalitet. Når vi skal vegleie personar med diabetes til eigenansvar og betre livskvalitet, er det difor viktig å ha kunnskap om dei faktorane som ser ut til å ha størst tyding for å betre metabolsk kontroll (18). Grey et al.(16) har forska på «coping skills training» (CST) blant ungdom med diabetes type $1 \mathrm{og}$ funne samanheng mellom CST og effekt på metabolsk kontroll og livskvalitet. Tidlegare forsking gir dermed føringar om at også dei psykososiale aspekt bør inkluderast i møte med desse pasientane, då dei ulike aspekta påverkar kvarandre.

\section{Utfordringar i dagliglivet}

Livet med diabetes kan være eit liv med håp og moglegheiter, men også eit liv prega av alvor og utfordringar. Lustman et al. (20) fann ein klar assosiasjon mellom høgt blodsukker og depresjon. Diabetes doblar risikoen for å utvikle ein følgjetilstand med depresjon, og kvinner er meir utsette enn menn (21). Før personen med diabetes vert utskriven kan vi be han beskrive korleis han vanlegvis reagerer på ein vanskelig situasjon, og korleis dei ter seg i høve til vanskane dei møter med å ha fătt diabetes (22). På denne måten kan vi kartlegge pasientar som nyttar lite konstruktive metode til å utvikle meir positive meistringsstrategiar. Meistring kan lærast! IIII

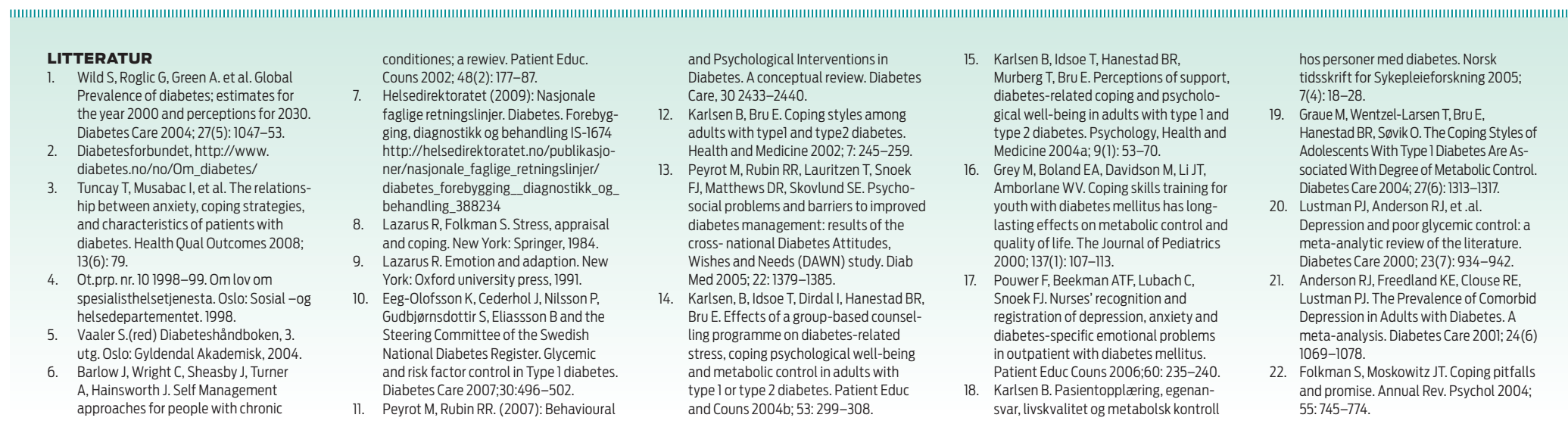

